\title{
PERMAINAN ULAR TANGGA DALAM MENGINGKATKAN KEMAMPUAN MORAL ANAK
}

\author{
Eka Setiawati ${ }^{1}$, Desri $^{2}$, Elih Solihatulmilah ${ }^{3}$ \\ PAUD dan Pendidikan Bahasa, STKIP Setia Budhi Rangkasbitung \\ Jl. Budi Utomo No 22L Komplek Pendidikan Rangkasbitung \\ 1echasetia14@gmail.com \\ 3elihsolihatul54@gmail.com \\ *PAUD \\ Kecamatan Cikotok Lebak \\ ²Desrithea@gmail.com
}

\begin{abstract}
Moral religion is important to develop because it will become the basis or foundation of children in navigating life. From the observation of the age of 3-4 years at KOBER PGRI Bayah, it was found that children's abilities in the aspects of religious moral development were relatively low. Based on the thinking about the factors causing the low moral capacity of the child's religion are: (1) teacher's body language is still difficult so that the presentation of learning is less interesting; (2) the use of methods that are less varied; (3) the lack of teaching aids owned; (4) avoiding children's interest in religious moral learning. This research uses Classroom Action Research. The results of the study show how to learn that can improve the moral capacity of religious children aged 3-4 years at KOBER PGRI Bayah, Lebak Regency. The success rate for activities is very significant. In the pre-cycle activities of the average percentage of $38.67 \%$ increased to $55.67 \%$ in the first cycle, and increased to $90.33 \%$ in the second cycle.
\end{abstract}

Keywords - kemampuan moral agama, game ular tangga

\begin{abstract}
Abstrak - Agama moral penting untuk dikembangkan karena akan menjadi dasar atau fondasi anak dalam menavigasi kehidupan. Dari pengamatan usia 3-4 tahun di KOBER PGRI Bayah, ditemukan bahwa kemampuan anak dalam aspek perkembangan moral keagamaan relatif rendah. Berdasarkan pemikiran tentang faktor-faktor yang menyebabkan rendahnya kapasitas moral agama anak adalah: (1) bahasa tubuh guru masih sulit sehingga presentasi pembelajaran kurang menarik; (2) penggunaan metode yang kurang bervariasi; (3) kurangnya alat bantu mengajar yang dimiliki; (4) menghindari minat anak-anak dalam pembelajaran moral agama. Penelitian ini menggunakan Penelitian Tindakan Kelas. Hasil penelitian menunjukkan bagaimana cara belajar yang dapat meningkatkan kapasitas moral anak-anak agama yang berusia 3-4 tahun di KOBER PGRI Bayah, Kabupaten Lebak. Tingkat keberhasilan untuk kegiatan sangat signifikan. Pada kegiatan pra siklus persentase rata-rata 38,67\% meningkat menjadi $55,67 \%$ pada siklus pertama, dan meningkat menjadi 90,33\% pada siklus kedua.
\end{abstract}

Kata kunci: kemampuan moral agama, game ular tangga 


\section{Pendahuluan}

Konsep moral sudah dapat dibentuk sejak masa anak, meskipun sudah dipelajari sejak kecil, namun setelah dewasa manusia tetap berhadapan dengan masalah-masalah moral dan meningkatkan konsep moralnya dalam berhubungan dengan orang lain. Bahwa perkembangan moral seorang anak sejalan dengan perkembangan kognitifnya. Dengan makin bertambahnya tingkat pengetahuan, makin banyak pula nilai-nilai moral. Menurut Hurlock (Sianawati,dkk, 1992) meskipun perkembangan peserta didik melewati pentahapan yang tetap, namun usia mereka dalam mencapai tahapan tertentu berbeda menurut tingkat perkembangan kognitif mereka. Pengembangan moral anak usia dini dilakukan agar terbentuk perilaku moral. Pembentukan perilaku moral pada anak, khususnya pada anak usia dini memerlukan perhatian serta pemahaman terhadap dasardasar serta berbagai kondisi yang mempengaruhi dan menentukan perilaku moral.

Memberikan landasan pendidikan moral dan agama kepada anak, seorang anak dapat belajar membedakan perilaku yang benar dan salah. Oleh karena itu seorang guru harus selalu berupaya dengan berbagai cara agar dapat membimbing anak agar mempunyai kepribadian yang baik, yang dilandasai dengan nilai moral dan agama. Keterampilan yang dilatih dalam permainan ular tangga di antaranya kemauan mengikuti dan mematuhi aturan permainan, bermain secara bergiliran

Berdasarkan uraian di atas, bahwa dari hasil observasi penulis mengungkapkan masih rendahnya perkembangan moral dan agama di KOBER PGRI Bayah terlihat dari beberapa anak yang masih bersendagurau saat berdo'a, baca surat pendek dan ketika praktek sholat, serta masih ada beberapa anak yang tidak memiliki tatakrama kepada guru atau orang dewasa serta kepada teman. Selain rendahnya kualitas perkembangan moral dan agama pada anak, ada hal lain yang menyebabkan pembelajaran moral dan agama tidak melekat pada anak yaitu metode yang digunakan guru monoton dan tidak menarik sehingga anak merasa jenuh.

\section{KAJIAN PUSTAKA}

I. Hakikat Moral dan Agama

Moral berasal dari bahasa latin, mos berarti kebiasaan dan dari sinilah asal kata moral atau moralitas (mores) yang berarti tata cara dalam kehidupan atau adat istiadat. Istilah moral selalu terkait dengan kebiasaan, aturan/tata cara suatu masyarakat tertentu, termasuk pula dalam moral adalah aturanaturan/nilai-nilai agama yang dipegang masyarakat setempat yaitu perilaku manusia yang sesuai dengan harapan, aturan, kebiasaan suatu kelompok masyarakat tertentu sebagaimana dikemukakan oleh Hurlock (Aisyah, 2010: 8.7) dalam mendefinisikan perilaku moral sebagai perilaku yang sesuai dengan kode moral kelompok sosial.

Menurut Megawangi (Aisyah dkk, 2010: 8.36) anak-anak akan tumbuh menjadi pribadi yang berkarakter apabila mereka berada di lingkungan yang berkarakter pula. Usaha mengembangkan anak-anak agar menjadi pribadi-pribadi yang bermoral/berkarakter baik merupakan tanggung jawab keluarga, sekolah, dan seluruh komponen masyarakat.

Sedangkan agama adalah aturan dan wahyu Tuhan yang sengaja diturunkan agar manusi hidup teratur, damai, sejahtera, bermartabat, dan bahagia baik di dunia maupun di akhirat. Ajaran agama juga berisi seperangkat norma yang akan menghantarkan manusia pada suatu peradaban masyarakat madani. (Hidayat, 2008: 7.3).

Dalam rangka mencapai keberhasilan pembentukan kepribadiann anak agar mampu terwarnai dengan nilai-nilai agama, maka perlu didukung oleh unsur keteladanan dari orang tua dan guru. Untuk tujuan tersebut dalam pelaksanaannya guru dapat mengembangkan strategi pembelajaran secara bertahap dan menyusun program kegiatan seperti program kegiatan rutinitas, program kegiatan terintegrasi, program kegiatan khusus. (Surtikanti dkk, 2012: 128). Yang dimaksudkan disini adalah moral keagamaan berarti nilai atau norma yang dijadikan pegangan bagi seseorang atau kelompok masyarakat yang mengatur tingkah laku dalam kehidupan yang didasarkan pada agama yang dianut.

Ada 3 strategi dalam pembentukan perilaku moral pada anak usia dini, yaitu: strategi latihan dan pembiasaan, Strategi aktivitas dan bermain, dan Strategi pembelajaran (Wantah, 2005: 109).

a. Strategi Latihan dan Pembiasaan 
Latihan dan pembiasaan merupakan strategi yang efektif untuk membentuk perilaku tertentu pada anak-anak, termasuk perilaku moral. Dengan latihan dan pembiasaan terbentuklah perilaku yang bersifat relatif menetap. Misalnya, jika anak dibiasakan untuk menghormati anak yang lebih tua atau orang dewasa lainnya, maka anak memiliki kebiasaan yang baik, yaitu selalu menghormati kakaknya atau orang tuanya.

b. Strategi Aktivitas Bermain

Bermain merupakan aktivitas yang dilakukan oleh setiap anak dapat digunakan dan dikelola untuk pengembangan perilaku moral pada anak. Menurut hasil penelitian Piaget (dalam Wantah, 2005: 116), menunjukkan bahwa perkembangan perilaku moral anak usia dini terjadi melalui kegiatan bermain. Pada mulanya anak bermain sendiri tanpa dengan menggunakan mainan. Setelah itu anak bermain menggunakan mainan namun dilakukan sendiri. Kemudian anak bermain bersama temannya bersama temannya namun belum mengikuti aturan-aturan yang berlaku. Selanjutnya anak bermain bersama dengan teman-temannya berdasarkan aturan yang berlaku.

\section{c. Strategi Pembelajaran}

Usaha pengembangan moral anak usia dini dapat dilakukan dengan strategi pembelajaran moral. Pendidikan moral dapat disamakan dengan pembelajaran nilai-nilai dan pengembangan watak yang diharapkan dapat dimanifestasikan dalam diri dan perilaku seseorang seperti kejujuran, keberanian, persahabatan, dan penghargaan (Wantah, 2005: 123).

Pembelajaran moral dalam konteks ini tidak semata-mata sebagai suatu situasi seperti yang terjadi dalam kelas-kelas belajar formal di sekolah, apalagi pembelajaran ini ditujukan pada anak-anak usia dini dengan cirri utamanya senang bermain. Dari segi tahapan perkembangan moral, strategi pembelajaran moral berbeda orientasinya antara tahapan yang satu dengan lainnya. Pada anak usia $0-2$ tahun pembelajaran lebih banyak berorientasi pada latihan aktivitas motorik dan pemenuhan kebutuhan anak secara proporsional. Pada anak usia antara $2-4$ tahun pembelajaran moral lebih diarahkan pada pembentukan rasa kemandirian anak dalam memasuki dan menghadapi lingkungan. Untuk anak usia 4-6 tahun strategi pembelajaran moral diarahkan pada pembentukan inisiatif anak untuk memecahkan masalah yang berhubungan dengan perilaku baik dan buruk.

Beberapa cara yang dilakukan orang tua untuk mengasah kecerdasan spiritual anak adalah sebagai berikut:

a. Memberi contoh

Anak usia dini mempunyai sifat suka meniru . karena orang tua merupakan lingkungan pertama yang ditemui anak, maka ia cenderung meniru apa yang diperbuat oleh orang tuanya. Di sinilah peran orang tua untuk memberikan contoh yang baik bagi anak, misalnya mengajak anak untuk ikut berdoa. Tatkala sudah waktunya shalat, ajaklah anak untuk segera mengambil air wudhu dan segera menunaikan sholat. Ajari shalat berjamaah dan membaca surat-surat pendek al-Qur'an dan Hadis-hadis pendek.

b. Melibatkan anak menolong orang lain.

Anak usia dini diajak untuk beranjangsana ke tempat orang yang membutuhkan pertolongan. Anak disuruh menyerahkan sendiri bantuan kepada yang membutuhkan, dengan demikian anak akan memiliki jiwa sosial.

c. Bercerita serial keagamaan

Bagi orang tua yang mempunyai hobi bercerita, luangkan waktu sejenak untuk meninabobokan anak dengan cerita kepahlawanan atau serial keagamaan. Selain memberikan rasa senang pada anak, juga menanamkan nilai-nilai kepahlawanan atau keagamaan pada anak dan konsisten dalam mengajarkannya. Dalam mengajarkan nilainilai spiritual pada anak diperlukan kesabaran, tidak semua yang kita lakukan berhasil pada saat itu juga, adakalanya memerlukan waktu yang lama dan berulang.

\section{Indikator Pengembangan Moral}

Berkaitan dengan perkembangan moral, Kholberg yang di kutip oleh Santrock membaginya menjadi tiga tahap, yaitu sebagai berikut : (Fadilah, 2012:48)

a. Preconventional reasining (penalaran prakonvensional) adalah tingkat yang paling rendah dalam teori perkembangan kohlberg. Pada tingkatan ini waktu anak masih kecil. Beberapa sikap orang tua yang perlu diperhatikan sehubungan dengan perkembangan moral anak diantaranya sebagai berikut: 
1) Konsisten dalam mendidik anak dilarang Ayah dan ibu harus memiliki sikap dan perlakuan yang sama dan melarang atau membolehkan tingkah laku tertentu kepada anak. Suatu tingkah laku anak yang dilarang oleh orang tua pada suatu waktu, harus juga dilarang apabila dilakukan kembali pada waktu lain.

2) Sikap orang tua dalam keluarga Secara tidal langsung, sikap orang tua terhadap anak, sikap ayang terhadap ibu, atau sebaliknya, dapat mempengaruhi perkembangan moral anak, yaitu melalui proses peniruan (imitasi). Sikap yang perlu dimiliki orang tua adalah sikap kasih sayang, keterbukaan, musyawarah (dialogis), dan konsisten.

3) Penghayatan dan pengalaman agama yang dianutOrang tua merupakan panutan (teladan) bagi anak, termasuk disini panutan dalam mengamalkan ajaran agama. Orang tua yang menciptakan iklim religius (agamis), dengan cara memberikan ajaran atau bimbingan tentang nilai-nilai agama kepada anak, maka anak akan mengalami perkembangan oral yang baik.

b. Sikap konsisten orang tua dalam menerapkan norma

Orang tua sebaiknya menjadi contoh positif bagi anak-anaknya, bukan hanya sekedar memberi contoh. Karena itu, orang -orang yang tak mempunyai hubungan harus harmonis dengan orang tuanya dimasa kecil. Kemungkinan besar tidak mampu mengembangkan superego yang cukup kuat, sehingga mereka bisa menjadi orang yang sering melanggar norma masyarakat.

- Conventional reasoning (penalaran post-konvensional) adalah tahap kedua atau tahap menengah dalam teori Kohlberg. Pada level ini, interaksi masih setengah-setengah (intermediet). Anak patuh secara internal pada standard tertentu, tetapi standard itu pada dasarnya ditetapkan oleh orang lain, seperti orangtua, atau oleh aturan sosial.

- Postconventional reasoning (penalaran post-konvensional) adalah level tertinggi dalam teori Kohlberg. Pada level ini moralitas telah sepenuhnya diinternalisasikan dan tidak didasarkan pada standar

\begin{abstract}
eksternal. Murid mengetahui aturan-aturan moral alternative, mengeksplorasi opsi, dan kemudian memutuskan sendiri kode moral apa yang terbaik bagi dirinya.
\end{abstract}

\section{Karakter Perkembangan Moral pada Anak Usia Dini}

Karakter perilaku moral pada anak usia dini menurut Teguh Waluyo (2013 : 47) dibagi menjadi 7 antara lain:

a. Tidak mengganggu teman yang sedang melakukan kegiatan.

b. Meminta tolong dengan baik

c. Mengucap salam jika bertemu atau berpisah

d. Selalu bersikap ramah

e. Berterimakasih jika memperoleh sesuatu.

f. Melaksanakan tata tertib yang ada di sekolah

g. Mengikuti aturan permainan

\section{Definisi Permainan Ular Tangga}

Menurut Melsi (2015: 10) ular tangga adalah permainan papan untuk anak-anak yang dimainkan oleh 2 orang atau lebih. Papan permainan dibagi dalam kotak-kotak kecil dan di beberapa kotak digambar sejumlah "tangga" atau "ular" yang menghubungkan dengan kotak lainnya. Ratnaningsih (2014:5) ular tangga adalah permainan yang menggunakan dadu untuk menentukan berapa langkah yang harus dijalani bidak.

Pengertian tersebut sesuai dengan pengertian dari Rahman 2010: dalam (http://repository.upi.edu/operator/upload/s_pau d_0803563), bahwa permainan ular tangga merupakan salah satu permainan papan yang ringan dan cukup populer di Indonesia selain permainan papan lain seperti monopoli, ludo, dam, dan halma. Pendapat tersebut didukung oleh pendapat Satya yang menyatakan bahwa permainan ular tangga bersifat ringan, sederhana, mendidik, menghibur, dan sangat interaktif jika dimainkan bersama-sama. Permainan ular tangga ini ringan jika dibawa, mudah dimengerti karena peraturan permainannya sederhana, mendidik, dan menghibur anak-anak dengan cara yang positif (Satya, 2012).

Berdasarkan uraian pengertian permainan ular tangga tersebut, maka dapat disimpulkan bahwa permainan ular tangga merupakan jenis permainan papan yang memiliki petak 
berjumlah 100, terbagi dalam 10 baris dan 10 kolom. Permainan ular tangga memiliki peraturan yang sederhana sehingga anak-anak mudah memainkannya.

Karakteristik permainan ular tangga termasuk media permainan, hal tersebut sesuai pendapat dari Arief S. Sadiman (2003: 75), bahwa permainan (games) adalah setiap kontes para pemain yang berinteraksi satu sama lain dengan mengikuti aturan-aturan tertentu untuk mencapai tujuan tertentu. Berkaitan dengan pendapat tersebut, Arief S. Sadiman menambahkan bahwa setiap permainan harus mempunyai komponen utama, yaitu:
a. Adanya pemain-pemain.
b. Adanya lingkungan untuk pemain berinteraksi.
c. Adanya aturan-aturan main.
d. Adanya tujuan-tujuan tertentu yang ingin.

Ular tangga termasuk media permainan yang tidak lepas dari adanya gambar atau foto yang ada di papan permainan ular tangga, seperti gambar ular dan tangga, maupun gambar lain sesuai tema ular tangga. Gambar atau foto berfungsi untuk menyampaikan pesan melalui gambar yang menyangkut indera penglihatan sehingga dapat menarik perhatian, mengilustrasikan fakta atau informasi (Cecep Kustandi dan Bambang Sutjipto, 2011: 41).

Sehubungan dengan hal tersebut, gambar atau foto termasuk media berbasis visual representasi. Hal itu sesuai dengan pendapat Cecep Kustandi dan Bambang Sutjipto, 2011: 87), bahwa media berbentuk visual dapat berupa gambar representasi seperti gambar lukisan atau foto yang menunjukkan bagaimana tampaknya suatu benda.

a. Strategi Permainan Ular Tangga

Strategi permainan ular tangga sebagaimana dijelaskan Alamsyah Said dan Andi Budimanjaya (2012: 240) merupakan jenis permainan antraktif yang melibatkan anak berperan aktif dalam ular tangga. kuatnya pola interaksi akyivitas siswa saat memainkan permainan ular tangga dalam kegiatan pembelajaran menyebabkan permainan ini sangat disenangi oleh siswa.

b. Prosedur Penerapan Permainan Ular Tangga Berikut langkah -langkah penerapan permainan ular tangga pada anak usia 3-4 tahun sebagaimana dijelaskan Alamsyah Said dan Andi Budimanjaya (2012: 240):
1) Siapkan kertas permainan ular tangga beserta dadu yang mempunyai mata enam.

2) Menyiapkan pertanyaan dan gambar yang disesuaikan dengan materi ajar yang akan dipelajari.

Menurut Ratnaningsih (2014: 6) manfaat media permainan ular tangga terdiri dari beberapa bagian yaitu :

1) Memberikan ilmu pengetahuan kepada anak melalui proses pembelajaran bermain sambil belajar.

2) Merangsang pengembangan daya pikir, daya cipta, dan bahasa agar mampu menumbuhkan sikap, mental, serta akhlak yang baik.

3) Menciptakan lingkungan bermain yang menarik, memberikan rasa aman, dan menyenangkan.

4) Mengenal kalah dan menang.

5) Belajar bekerja sama dan menunggu giliran.

c. Kelebihan dan Kekurangan Permainan Ular Tangga

Menurut Melsi (2015: 12) kelebihan dan kekurangan media permainan ular tangga terdiri dari beberapa bagian yaitu:

1) Kelebihan

a) Pada permainan ini mampu melatih sikap siswa untuk mengantri dalam memulai pengocokan/permainan.

b) Melatih kognitif siswa saat menjumlahkan mata ular saat dadu keluar.

c) Melatih kerjasama

d) Memotivasi siswa agar terus belajar karena belajar adalah hal yang menyenangkan dan mengasyikan, bukan lagi sesuatu yang hanya harus terpaku pada lembaranlembaran soal ulangan.

e) Media ular tangga ini sangat efektif untuk mengulang (review) pelajaran yang telah diberikan.

f) Media ini sangat praktis dan ekonomis serta mudah dimainkan.

g) Dapat meningkatkan antusias anak dalam menggunakan media pembelajaran ini.

h) Siswa akan menjawab pertanyaan dengan sungguh-sungguh apabila mereka berhenti di kotak pertanyaan.

i) Media ini sangat disenangi oleh anak karena banyak terdapat gambar yang menarik dan full colour.

2) Kekurangan 
a) Membutuhkan persiapan yang matang agar menyesuaikan konsep materi dan kegiatan pembelajaran.

b) Jika terdapat siswa yang cenderung cepat bosan maka ia akan kehilangan minat untuk bermain.

c) Penggunaan media permainan ular tangga memerlukan banyak waktu untuk menjelaskan kepada anak.

d) Permainan ular tangga tidak dapat mengembangkan semua materi pembelajaran.

e) Kurangnya pemahaman aturan permainan oleh anak dapat menimbulkan kericuhan.

f) Jika siswa turun tangga maka kemungkinan mendapatkan jenis soal yang sama.

\section{METODE PENELITIAN}

Penelitian ini menggunakan metode penelitian tindakan kelas yang mengadipsi model dari Suharsimi arikunto

TABEL I KISI-KISI INSTRUMEN

\begin{tabular}{|c|c|c|}
\hline Variabel & Indikator & $\begin{array}{l}\text { Aspek yang } \\
\text { Diamati }\end{array}$ \\
\hline \multirow{10}{*}{$\begin{array}{l}\text { Kemampua } \\
\mathrm{n} \text { moral } \\
\text { agama } \\
\text { anak } \\
\text { melalui } \\
\text { permainan } \\
\text { ular tangga }\end{array}$} & \multirow{2}{*}{$\begin{array}{l}\text { Mengetahui arti } \\
\text { kasih dan sayang } \\
\text { kepada ciptaan } \\
\text { Allah }\end{array}$} & $\begin{array}{l}\text { Menjaga } \\
\text { kebersihan } \\
\text { lingkungan }\end{array}$ \\
\hline & & $\begin{array}{l}\text { Menyayangi } \\
\text { teman }\end{array}$ \\
\hline & \multirow[t]{6}{*}{$\begin{array}{l}\text { Meniru do'a pendek } \\
\text { sesuai agamanya }\end{array}$} & $\begin{array}{l}\text { Do'a sebelum dan } \\
\text { sesudah belajar }\end{array}$ \\
\hline & & $\begin{array}{l}\text { Do'a sebelum dan } \\
\text { sesudah makan }\end{array}$ \\
\hline & & $\begin{array}{l}\text { Do'a sebelum dan } \\
\text { bangun tidur }\end{array}$ \\
\hline & & $\begin{array}{l}\text { Do'a untuk kedua } \\
\text { orang tua }\end{array}$ \\
\hline & & $\begin{array}{l}\text { Do'a kebaikan } \\
\text { dunia akhirat }\end{array}$ \\
\hline & & Praktek sholat. \\
\hline & \multirow{2}{*}{$\begin{array}{l}\text { Mengetahui prilaku } \\
\text { yang berlawanan } \\
\text { (baik-buruk, benar- } \\
\text { salah, sopan-tidak } \\
\text { sopan) }\end{array}$} & $\begin{array}{l}\text { Cara berbicara } \\
\text { secara santun }\end{array}$ \\
\hline & & $\begin{array}{l}\text { Cara meminta } \\
\text { bantuan kepada } \\
\text { teman. }\end{array}$ \\
\hline
\end{tabular}

\section{PEMBAHASAN}

Dari hasil tindakan pada siklus I dan siklus II, diperoleh hasil penelitian meningkatkan kemampuan moral agama anak melalui permainan ular tangga berhasil meningkat dari pra penelitian sebesar $38,67 \%$, meningkat pada siklus satu sebesar $55,67 \%$ dan mengalami peningkatan pada siklus dua sebesar 90,33\%. Kemampuan moral agama mengalami peningkatan pada anak karena adanya kesadaran dari guru begitu pentingnya menanamkan moral agama sejak dini dan untuk mencapai itu perlu stumulasi dan pembelajaran yang menyenangkan dan bermakna bagi anak. Interaksi guru dan peserta didik juga ditingkatkan. Berdasarkan keriteria ketuntasan belajar yaitu $75 \%$ sudah dinyatakan berhasil dalam penelitian

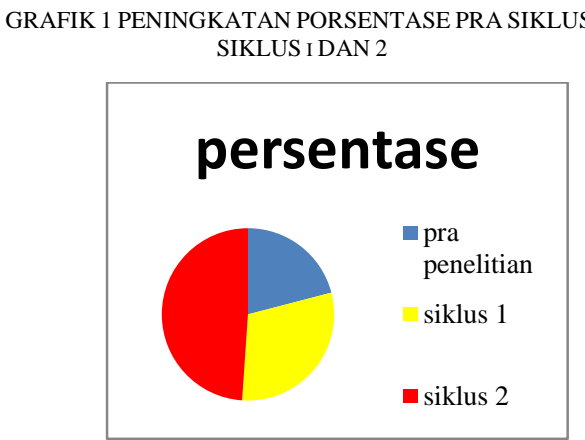

Berdasarkan data diatas, terdapat peningkatan prosentase pada kemampuan moral agama anak melalui permainan ular tangga setelah dilakukan tindakan siklus I dan siklus II. Berikut tabel dari pra penelitian sampai siklus II:

TABEL II ANALISIS HASIL SIKLUS 1 DAN II

\begin{tabular}{|c|c|c|c|}
\hline $\begin{array}{c}\text { Persenta } \\
\text { se Pra } \\
\text { Penelitia } \\
\text { n }\end{array}$ & $\begin{array}{c}\text { Persen } \\
\text { tase } \\
\text { Siklus } \\
\text { I }\end{array}$ & $\begin{array}{c}\text { Persen } \\
\text { tse } \\
\text { Siklus } \\
\text { II }\end{array}$ & \\
\hline $38,67 \%$ & $\begin{array}{c}55,67 \\
\%\end{array}$ & $\begin{array}{c}90,33 \\
\%\end{array}$ & $\begin{array}{lr}\text { Persentase } & \text { pada } \\
\text { siklus II lebih besar } \\
\text { dari pada persentase } \\
\text { siklus 1 dalam } \\
\text { peningkatan } \\
\text { kemampuan moral } \\
\text { agama anak dan } \\
\text { persentase } \\
\text { penelitian pra } \\
\text { meningkat pada } \\
\text { siklus I sehingga } \\
\text { dapat disimpulkan } \\
\text { bahwa } \\
\text { menggunakan } \\
\text { permainan } \\
\text { tangga ular } \\
\text { meningkatkan dapat } \\
\text { kemampuan moral } \\
\text { agama anak usia } 3-4 \\
\text { tahun. }\end{array}$ \\
\hline
\end{tabular}


Terdapat peningkatan nilai kemampuan moral agama anak dengan permainan ular tangga, berdasarkan hasil analisa, peneliti menyimpulkan hal ini terjadi karena kegiatan pembelajaran meningkatkan kemampuan aspek moral agama dilakukan dengan menggunakan metode permainan ular tangga. Selain dipengaruhi oleh media, keberhasilan peningkatan kemampuan moral agama dengan permainan ular tangga juga dipengaruhi dengan keterampilan guru dalam mengajar dan menstimulasi anak untuk meningkatkan kemampuan moral gama dengan metode permaianan ular tangga dan mengungkapkan pendapatnya.

Meningkatkan kemampuan moral agama dengan permainan ular tangga tergantung pada pada banyaknya peluang yang disediakan tentang keterlibatan dalam penggunaan media yang disediakan oleh kolaborator. Untuk mengeksplorasi interaksi dan kemampuan moral agama anak, tanggapan kolaborator dalam menanggapi anak harus dilakukan dengan praktek yang berhubungan dengan moral agama, dengan praktek anak melakukan langsung sehingga akan lebih mudah diingat oleh anak

\section{DAFTAR PUSTAKA}

[1] Atiqoh, Lia Nur. (2011). Permainan Ular Tangga sebagai Media Pembentuk Karakter. Malang: ArRuzz

[2] Budiningsih, Astri. (2012). Belajar dan Pembelajaran. Jakarta: PT Rineka Cipta

[3] Elizabeth Hurlock. (1996). Perkembangan Anak. Jakarta: Erlangga

[4] Indriana, Dina. (2011). Ragam Alat Bantu Media Pengajaran. Bandung: DIVA Press I.S.

[5] Jalaluddin. ( 1996) Psikologi Agama. Jakarta: PT RajaGrafindo Persada 